\title{
Psychometric properties of the Revised Children's Manifest Anxiety Scale-Second Edition in Peruvian students
}

\author{
Alicia Boluarte Carbajal; Frank Antony Grillo Delgado; \\ Karla Alejandra Castellanos-Huerta; Arnold Alejandro Tafur-Mendoza
}

Cómo citar este artículo:

Boluarte Carbajal, A., Grillo Delgado, F. A., Castellanos-Huerta, K.A., \& Tafur-Mendoza, A. A. (2021). Psychometric properties of the Revised Children's Manifest Anxiety Scale-Second Edition in Peruvian students. Acta Colombiana de Psicologia, 24(2), 35-44. https://www.doi.org/10.14718/ACP.2021.24.2.4

Recibido, mayo 14/2020; Concepto de evaluación, enero 13/2021; Aceptado, abril 19/2021

\author{
Alicia Boluarte Carbajal ${ }^{1}$ \\ ORCID: https://orcid.org/0000-0002-8316-8065 \\ Universidad César Vallejo, Los Olivos, Perú \\ Frank Antony Grillo Delgado \\ ORCID: https://orcid.org/0000-0001-7592-1283 \\ Universidad César Vallejo, Callao, Perú \\ Karla Alejandra Castellanos-Huerta \\ ORCID: https://orcid.org/0000-0002-9061-8319 \\ Universidad de Guadalajara, Jalisco, México \\ Arnold Alejandro Tafur-Mendoza \\ ORCID: https://orcid.org/0000-0001-8331-1098 \\ Universidad del Pacífico, Lima, Perú \\ Universidad Nacional Mayor de San Marcos, Lima, Perú
}

\begin{abstract}
The aim of this study was to analyze the psychometric properties of the Revised Children's Manifest Anxiety Scale-Second Edition (RCMAS-2) among Peruvian students. The sample consisted of 472 participants aged between 7 and 18 years, of whom 250 were female (53\%). Likewise, 191 were enrolled from third to sixth grade of primary school $(40.5 \%)$, and 281 were registered from first to fifth grade of secondary school (59.5\%). The results of the study indicated that the RCMAS-2 scores had adequate levels of reliability for all its dimensions (ordinal alpha $>.70$ ). On the other hand, a four-factor structure (Physiological anxiety, Worry/Social anxiety, Defensiveness I, and Defensiveness II) was found to be invariant to gender and schooling level. Also, convergent and discriminant validity evidence was provided. Finally, a moderate difference in Defensiveness II according to the schooling level through the latent mean structure analysis was found. Taking into account the results, it was concluded that the RCMAS-2 scores have evidence of reliability, validity, and equity for its use in Peruvian regular elementary school students.

Keywords: RCMAS-2, anxiety, psychometric properties, factorial invariance, Peruvian students.
\end{abstract}

\footnotetext{
1 We applied the first-last-author-emphasis norm (FLAE) for the sequence of authors. Correspondence concerning this article should be addressed to Alicia Boluarte Carbajal, Escuela Profesional de Psicología, Universidad César Vallejo, 15314 Los Olivos, Perú. Email: aliciabolucar@gmail.com.
} 


\title{
Propiedades psicométricas de la Escala de Ansiedad Manifiesta en Niños Revisada, Segunda Edición, en estudiantes peruanos
}

\begin{abstract}
Resumen
El objetivo del estudio fue analizar las propiedades psicométricas de la Escala de Ansiedad Manifiesta en Niños Revisada, Segunda Edición (CMASR-2), en estudiantes peruanos. La muestra estuvo conformada por 472 participantes con edades entre 7 y 18 años, siendo 250 mujeres (53\%). Asimismo, 191 pertenecían del tercero al sexto grado de primaria (40.5\%) y 281 cursaban del primero al quinto grado de secundaria (59.5\%). Los resultados del estudio indicaron que las puntuaciones en el CMASR-2 presentan adecuados niveles de fiabilidad para todas sus dimensiones (alfa ordinal > .70). Por otro lado, se encontró una estructura de cuatro factores (Ansiedad fisiológica, Inquietud/Ansiedad social, Defensividad I y Defensividad II) que se mantuvo invariante al sexo y nivel de escolaridad. Además, se aportaron evidencias de validez discriminante y convergente. Finalmente, el análisis de medias latentes encontró una diferencia moderada en Defensividad II según el nivel de escolaridad. A partir de los resultados, se concluyó que, las puntuaciones en el CMASR-2 cuentan con evidencias de fiabilidad, validez y equidad para su uso en estudiantes peruanos de educación básica regular.

Palabras clave: CMASR-2, ansiedad, propiedades psicométricas, invarianza factorial, estudiantes peruanos.
\end{abstract}

\section{Introduction}

According to the World Health Organization (2020), anxiety was the sixth cause of disability and illnesses in children from 10 to 14 years old and the ninth cause in adolescents from 15 to 19 years old worldwide in 2020 . In this sense, according to Cohen et al. (2018), 10\% of minors from 6 to 17 years old, approximately 117 million, would have suffered from some kind of anxiety disorder. Similarly, a meta-analysis of 41 studies in 27 countries reported that anxiety disorders were present in $6.5 \%$ of children and adolescents (Polanczyk et al., 2015).

In Peru, according to the National Institute of Mental Health (Instituto Nacional de Salud Mental [INSM], 2012) in 2007, the prevalence of anxiety disorders in children between 6 and 10 years old was 3\%. Also, in adolescents between 11 and 18 years old, there was a prevalence of generalized anxiety disorder of $5.2 \%$, where the highest prevalence was in adolescents between 15 and 18 years old (6.3\%). The following year, the INSM (2013) undertook a new epidemiologic study and concluded that the prevalence of generalized anxiety disorder in adolescents from 12 to 17 years old was $3 \%$ with similar rates between males (3.1\%) and females (3\%). Besides, the Ministry of Health (Ministerio de Salud, 2018) states that the annual prevalence of anxiety disorder in people aged 12 years and over is 5.9\% on average, and that, between 2009 and 2017, the number of cases of anxiety treated at health facilities went from 165,461 to 245,503 , which is higher than depression and other disorders' cases.
It is important to highlight that the prevalence of anxiety disorders varies according to the measurement instrument utilized; for example, Puerto Rico had a prevalence of $2.9 \%$ in children from 4 to 17 years old according to the results presented by the Diagnostic Interview Schedule for Children (DISC-IV) (Shafferet al., 2000). In Brazil, the Evaluation of Development and Well-Being Assessment(DAWBA) was used, and it was found that there was a prevalence of $5.2 \%$ among children aged from 7 to 14 years. In Mexico, a prevalence of $29.8 \%$ was evidenced through the Composite International Diagnostic Interview (CIDI-A). While in Chile, it was determined that $7.4 \%$ of children had an anxiety disorder after administering questionnaires and semi-structured interviews (Flora de la Barra, 2009).

In the Peruvian context, there is a lack of instruments to measure anxiety in children since most of them were created for the adult population and, to a lesser extent, for adolescents (Domínguez et al., 2013). One of the tests that have been used in children is the Anxiety Checkup List for Children (Vega et al., 2005), while for adolescents, there is the State-Feature Anxiety Inventory STAI (Celis et al., 2001) and the General Questionnaire of Health GHQ-12 (Gelaye et al., 2015). Thus, an instrument to measure anxiety is the Revised Children's Manifest Anxiety Scale-Second Edition (RCMAS-2), which evaluates children aged six years and over (Reynolds \& Richmond, 2008). One advantage of this test is that, besides measuring the normal and pathological levels of anxiety, it identifies the type of anxiety the examined patient suffers from as well.

The first version was the CMAS, which was composed of 53 items and was developed by McCandless et al. (1956). 
Subsequently, Reynolds and Richmond (1978) created a revised version of 37 items (RCMAS) with a five-factor structure: Physiologic anxiety, Worry, Social anxiety, and two Lie factors. A second edition of the revised version was published in 2008, the RCMAS-2, composed of 49 items grouped into five scales: Physiological anxiety, Worry, Social anxiety, Defensiveness, and Inconsistent responding index (Reynolds \& Richmond, 2008).

The psychometric properties of the RCMAS-2 have been analyzed in different contexts. Zhu and Lowe (2017) made a Chinese adaptation in which they found four factors (Physiological anxiety, Worry/Social anxiety, Defensiveness I, and Defensiveness II). They obtained adequate levels of internal consistency, except Physiological anxiety. Similar results were obtained by Cha et al. (2020) in a sample of Korean elementary students. On the other hand, Ahmad and Mansoor (2011) made the Pakistani adaptation and obtained low levels of internal consistency $(\alpha<.70)$, except for Worry $(\alpha=.71)$. The study by Raad (2013) stated that the RCMAS- 2 was administered in students with specific learning problems and reported a three-factor structure (Physiological anxiety, Worry, and Social anxiety) with adequate levels of reliability and convergent and discriminant validity evidence. Similarly, the studies by Lowe (2014) and Ang et al. (2011) found a five-factor structure (Physiological anxiety, Worry, Social anxiety, Defensiveness I, and Defensiveness II), with acceptable internal consistency estimates of reliability $(\alpha>$.70).

However, the use of the RCMAS-2 is not restricted only to educational contexts since it has also been used in the clinical field (Mahakwe et al., 2021). In a group of 370 children with cancer, Wuet al. (2016) found adequate reliability levels with exception of the Physiological anxiety factor $(\alpha=.65)$. Also, the confirmatory factorial analysis tested a three-factor structure (Physiological anxiety, Worry, and Social anxiety), although it did not have a correct fit.

Finally, nowadays equity or bias absence is considered an indispensable requisite for all measurement scales because it assures that the instrument's contents have the same meaning concerning the evaluated construct within the different categories of a sociodemographic variable (Aliaga, 2018). In this sense, the literature indicates that the RCMAS-2 meets this criterion in other realities (Ang et al., 2011; Lowe, 2014). However, given that anxiety is affecting children and adolescents more and more (Orgilés et al., 2012), it is necessary to verify this psychometric property through gender and schooling level in the sample composed of Peruvian students.

Therefore, this study seeks to analyze the psychometric properties of RCMAS-2 in a sample of Peruvian children and adolescents. Likewise, the study seeks to compare latent means among the found factors according to the participants' gender and schooling level.

\section{Method}

\section{Design}

The study was instrumental because the RCMAS-2 psychometric properties were examined (Ato et al., 2013). These properties refer to the scores' reliability, validity, and equity which were obtained after administering a test (Aliaga, 2018). The methodological planning followed different directives for instrumental studies (American Educational Research Association et al., 2014; Zickar, 2020).

\section{Participants}

The initial sample was comprised of 488 students of regular basic education, obtained through a non-probability sampling (purposive sample), who belonged to a public educational institution of the Constitutional Province of Callao, Peru. From the sample, 16 were not considered because of having a different nationality. The final sample was composed of 472 students aged between 7 and 18 years $(M=12.46$, $S D=2.56)$. The students were enrolled in different grades, from third to sixth in Primary $(n=191,40.50 \%)$ and from first to fifth in Secondary $(\mathrm{n}=281,59.50 \%)$. Most of the students were female $(n=250,53.00 \%)$, who studied in the morning shift $(n=305,64.60 \%)$ and lived in Callao $(n=422,89.40 \%)$.

\section{Instrument}

The RCMAS-2 is a self-report instrument developed by Reynolds and Richmond (2008). For this study, the Spanish version of the RCMAS-2 was used (Reynolds \& Richmond, 2012). The RCMAS-2 is made up of 49 items; whose objective was to measure the anxiety level and nature in children and adolescents aged between 6 and 19 years. The answer format is dichotomous (yes $=1$ and no $=0$ ). The RCMAS-2 is composed of five scales: Physiological anxiety (12 items), Worry (16 items), Social anxiety (12 items), Defensiveness ( 9 items), and Inconsistent responding index. The combination of the first three scales gives a score for total anxiety, while the last two refer to the validity of the application. The RCMAS- 2 has adequate psychometric properties in its original study with an alpha coefficient higher than .70 in all the scales and an exploratory factor analysis determined the presence of three related factors (Reynolds \& Richmond, 2008). 


\section{Procedure}

Data collection started with the obtaining of permission of the educational institution' director. Subsequently, the schedule of the instrument application was coordinated with the teachers and gave informed consent to all the students where the objective of the study was explained and ensured the confidentiality of their answers. This consent was signed by the sample students' parents or caretakers and, afterward, it was given back to the examiners before the RCMAS-2 administration. The students completed the scale voluntarily during classes, which took between 15 and 20 minutes.

Once the database was obtained, the pattern of missing values was examined through the Little test for missing completely at random data [MCAR] (Little, 1988). The pattern of missing values was random $\left(\chi^{2}=112.00, \mathrm{df}=\right.$ $144, p=.978)$, with less than $5 \%$ of them per variable. Therefore, the pairwise method was used to manage the missing values.

\section{Ethical statement}

The ethical aspects of the study were approved by the Ethics Committee of the Universidad César Vallejo, Lima, Peru, which evaluated the research project and the informed consent. All procedures performed in the study involving human participants were following the 1964 Helsinki declaration and its later amendments or comparable ethical standards, and in compliance with the code of ethics of the Colegio de Psicólogos del Perú. In the informed consent, it was stated that the study activities did not present any risk for the participants, also ensuring the conditions of confidentiality, the anonymity of the responses, use of the information and terms of publication of the results. Likewise, the respect, dignity, privacy, well-being and rights of the participants were safeguarded throughout the study.

\section{Data analysis}

The descriptive analysis of the items was done through the mean and standard deviation. Validity evidence based on the internal structure was collected through the confirmatory factor analysis (CFA). Diagonally Weighted Least Squares (DWLS) with robust standard errors were used, based on a matrix of tetrachoric correlations (DiStefanoet al., 2018). The goodness-of-fit indices used were Root Mean Square Error of Approximation (RMSEA), Standardized Root Mean Square Residual (SRMR), Comparative Fit Index (CFI), Tucker-Lewis Index (TLI), and Weighted Root Mean Square Residual (WRMR). Thus, the following values were considered acceptable: RMSEA $<.05$, SRMR $<.08$, CFI $>.90$, TLI $>.90$, and WRMR $<1.00$ (DiStefano et al., 2018; Keith, 2019). For the respecification of the models, the magnitude of modification indices was considered for correlated errors so its presence can have a theoretical justification (Dominguez-Lara, 2019).

For the bias analysis, the RCMAS-2 factorial invariance through the multi-group CFA(MGCFA) according to gender and schooling level was tested. The MGCFA followed $\mathrm{Wu}$ and Estabrook's (2016) proposal, using theta parameterization and restricting parameters equality sequentially. In the first evaluation, the baseline model obtained was established through the CFA for the referred groups (configurational invariance). For the second evaluation, the factor loadings, intercepts, and thresholds were equalized (scalar invariance). Additionally, in the third evaluation equality of means was added. The goodness-of-fit indices used were the same that in CFA, considering the following differences $(\Delta)$ among these indexes: $\Delta \mathrm{CFI}<.010, \Delta \mathrm{TLI}<.010$, and $\Delta$ RMSEA $<.010$ invariance criteria (Rutkowski \& Svetina, 2017).

Validity evidence based on the relationship with other variables was gathered from convergent and discriminant evidence. The convergent evidence was evaluated through average variance extracted (AVE), accepting values over .500 (Hair et al., 2019) as a general criterion. However, for a more precise evaluation, the criteria established by Moral (2019) was followed. The discriminant evidence was evaluated through the heterotrait-monotrait ratio (HTMT), where values under .850 (Henseler et al., 2015) were accepted.

For the scores' reliability analysis, the internal consistency method through the ordinal coefficient alpha (Zumbo et al., 2007) was used and values over .70 were considered appropriate (Nunnally \& Bernstein, 1994). Additionally, for a more complete evaluation of reliability, the means and standard deviations of the matrix of tetrachoric inter-item correlations were obtained (Ventura-León \& Peña-Calero, 2020).

The latent means difference according to gender and schooling level was evaluated through the effect size estimation (Hancock, 2001). This coefficient is analogous to Cohen's d effect size, for which values $0.20,0.50$, and 0.80 , were considered small, medium, and large effect respectively (Cohen, 1988).

The analysis was done through the $\mathrm{R}$ software version 4.0.4 (R Core Team, 2021), using the packages by BaylorEdPsych version 0.5 (Beaujean, 2012), lavaan version 0.6-8 (Rosseel, 2012), psych version 2.1.3 (Revelle, 2020), and semTools version 0.5-4 (Jorgensen et al., 2021). 


\section{Results}

Items analysis

The items' means were from .182 (item 28) to .841 (item 40), where higher values indicated a higher proportion of students who chose the "yes" answer. The standard deviations were between .366 (item 40) and .501 (item 31 and item 9), indicating a higher variability of answers in higher values (Table 1).

\section{Validity evidence based on internal structure}

Six models were tested through the CFA (Table 2). The first model was composed of five factors (Ang et al., 2011). The second model was the respecification of the first with two correlated errors added, item 23 with item 37 and item 4 with item 10. The third model was composed of four factors (Zhu \& Lowe, 2017). The fourth model was the respecification of the third, with five correlated errors added, item 23 with item 37 (.636), item 4 with item 10 (.791), item 17 with item 10 (.681), item 17 with item 4 (.610), and item 23 with item 41 (.407). The fifth model was comprised of three factors (Wu et al., 2016). The sixth model was the respecification of the fifth with two correlated errors added, item 23 with item 37 and item 4 with item 10 .

The models with the best goodness-of-fit indices were the fourth (modified four-factor) and the sixth (modified three-factor). In both models, the RMSEA, CFI, and TLI had satisfactory values, which is not the case for SRMR and WRMR. However, the evaluation of the goodnessof-fit indices was done globally. The difference between both models was not significant $(\triangle \mathrm{RMSEA}=.002, \Delta \mathrm{CFI}$ $=.009$, and $\Delta \mathrm{TLI}=.009$ ); therefore, the two models were considered for the factorial invariance.

\section{Equity}

The evaluation of configurational invariance for the three-factor model modified according to gender indicated that the covariance matrix of latent variables was not positive definite in the group of females, because the Worry and Social anxiety factors had a correlation of 1.029. Hence, this model was excluded from the current and subsequent analysis.

Regarding the invariance for the four-factor model modified according to gender and schooling level (Table 3), the configurational model showed an adequate fit (RMSEA $<.05$, CFI > .90, and TLI > .90). Subsequently, the metric invariance produced small changes on the goodness-of-fit indices $(\triangle \mathrm{RMSEA}<.010, \Delta \mathrm{CFI}<.010$, and $\Delta \mathrm{TLI}<.010)$, where the invariance level was considered satisfactory.
Table 1.

Descriptive analysis of the modified four-factor model's items and factor loadings

\begin{tabular}{|c|c|c|c|c|c|c|}
\hline \multirow[b]{2}{*}{ Item } & \multirow[b]{2}{*}{$M$} & \multirow[b]{2}{*}{$S D$} & \multicolumn{4}{|c|}{ Factor loadings } \\
\hline & & & PA & W/SA & D-I & D-II \\
\hline 15 & .267 & .443 & .641 & & & \\
\hline 39 & .492 & .500 & .561 & & & \\
\hline 7 & .383 & .487 & .556 & & & \\
\hline 34 & .426 & .495 & .523 & & & \\
\hline 43 & .532 & .500 & .504 & & & \\
\hline 46 & .415 & .493 & .500 & & & \\
\hline 25 & .549 & .498 & .485 & & & \\
\hline 1 & .377 & .473 & .443 & & & \\
\hline 20 & .553 & .498 & .421 & & & \\
\hline 5 & .288 & .453 & .418 & & & \\
\hline 31 & .504 & .501 & .362 & & & \\
\hline 11 & .643 & .480 & .308 & & & \\
\hline 26 & .375 & .485 & & .613 & & \\
\hline 32 & .665 & .472 & & .610 & & \\
\hline 22 & .352 & .478 & & .579 & & \\
\hline 10 & .324 & .469 & & .574 & & \\
\hline 30 & .515 & .500 & & .555 & & \\
\hline 18 & .460 & .499 & & .553 & & \\
\hline 16 & .337 & .473 & & .552 & & \\
\hline 9 & .498 & .501 & & .548 & & \\
\hline 4 & .322 & .468 & & .547 & & \\
\hline 27 & .417 & .494 & & .546 & & \\
\hline 17 & .430 & .496 & & .541 & & \\
\hline 35 & .644 & .479 & & .513 & & \\
\hline 42 & .275 & .447 & & .508 & & \\
\hline 36 & .301 & .459 & & .478 & & \\
\hline 8 & .341 & .475 & & .475 & & \\
\hline 2 & .542 & .499 & & .452 & & \\
\hline 37 & .369 & .483 & & .450 & & \\
\hline 49 & .532 & .500 & & .448 & & \\
\hline 41 & .426 & .495 & & .444 & & \\
\hline 45 & .322 & .468 & & .441 & & \\
\hline 3 & .746 & .436 & & .437 & & \\
\hline 47 & .312 & .464 & & .380 & & \\
\hline 13 & .388 & .488 & & .373 & & \\
\hline 12 & .621 & .486 & & .358 & & \\
\hline 6 & .292 & .455 & & .355 & & \\
\hline 28 & .182 & .386 & & .347 & & \\
\hline 23 & .432 & .496 & & .336 & & \\
\hline 21 & .659 & .475 & & .307 & & \\
\hline 29 & .676 & .469 & & & .823 & \\
\hline 19 & .737 & .441 & & & .777 & \\
\hline 33 & .686 & .464 & & & .766 & \\
\hline 24 & .447 & .498 & & & .751 & \\
\hline 38 & .397 & .490 & & & .622 & \\
\hline 14 & .699 & .459 & & & .375 & \\
\hline 44 & .689 & .464 & & & & .873 \\
\hline 48 & .767 & .423 & & & & .700 \\
\hline 40 & .841 & .366 & & & & .497 \\
\hline
\end{tabular}

Note. $M=$ Mean; $S D=$ Standard deviation; $\mathrm{PA}=$ Physiological anxiety; W/SA = Worry/Social anxiety; D-I = Defensiveness I; D-II $=$ Defensiveness II. 
Table 2.

Results of confirmatory factor analysis for the RCMAS-2

\begin{tabular}{ccccccccc}
\hline Model & \multicolumn{1}{c}{$X^{2}$} & $\mathrm{df}$ & $\chi^{2} / \mathrm{df}$ & $\begin{array}{c}\text { RMSEA } \\
{[90 \% \mathrm{CI}]}\end{array}$ & CFI & TLI & SRMR & WRMR \\
\hline 1. Five-factors & 2360.088 & 1117 & 2.113 & $.049[.046 ; .052]$ & .882 & .876 & .099 & 1.388 \\
2. Five-factors(m) & 2176.121 & 1115 & 1.952 & $.045[.042 ; .048]$ & .899 & .894 & .096 & 1.333 \\
3. Four-factors & 2430.271 & 1121 & 2.168 & $.050[.047 ; .053]$ & .876 & .870 & .100 & 1.409 \\
4. Four-factors(m) & 2027.450 & 1116 & 1.817 & $.042[.039 ; .045]$ & .914 & .909 & .094 & 1.286 \\
5. Three-factors & 1572.165 & 737 & 2.133 & $.049[.046 ; .053]$ & .903 & .897 & .095 & 1.385 \\
6. Three-factors(m) & 1397.701 & 735 & 1.902 & $.044[.040 ; .047]$ & .923 & .918 & .091 & 1.306 \\
\hline
\end{tabular}

Note. RMSEA = Root Mean Square Error of Approximation; $\mathrm{CI}=$ Confidence Interval; CFI = Comparative Fit Index; TLI = TuckerLewis Index; SRMR = Standardized Root Mean Square Residual; WRMR = Weighted Root Mean Square Residual.

Table 3.

Factorial invariance for the four-factor model modified according to gender and schooling level

\begin{tabular}{|c|c|c|c|c|c|}
\hline Model & $\chi^{2}$ & $\mathrm{df}$ & $\operatorname{RMSEA}(\Delta)$ & $\mathrm{CFI}(\Delta)$ & $\operatorname{TLI}(\Delta)$ \\
\hline \multicolumn{6}{|c|}{ Schooling level } \\
\hline Configural & 2993.037 & 2232 & .038 & .934 & .930 \\
\hline Strong & 3125.658 & 2273 & $.040(.002)$ & $.926(.008)$ & $.923(.007)$ \\
\hline Means & 3148.371 & 2277 & $.040(.000)$ & $.924(.002)$ & $.922(.001)$ \\
\hline \multicolumn{6}{|l|}{ Gender } \\
\hline Configural & 3125.709 & 2232 & .041 & .918 & .913 \\
\hline Strong & 3202.568 & 2273 & $.042(.001)$ & $.915(.003)$ & $.912(.001)$ \\
\hline Means & 3292.093 & 2277 & $.044(.002)$ & $.907(.008)$ & $.904(.008)$ \\
\hline
\end{tabular}

Note. RMSEA = Root Mean Square Error of Approximation; CFI = Comparative Fit Index; TLI = Tucker-Lewis Index; $\Delta=$ Difference

Finally, the means invariance also had a small discrepancy $(\Delta \mathrm{RMSEA}<.010, \Delta \mathrm{CFI}<.010$, and $\Delta \mathrm{TLI}<.010)$. These results prove the factorial invariance in the three levels according to gender and schooling level.

Validity evidence based on the relationship with other variables

Regarding convergent evidence measured through the AVE, only the Defensiveness II factor had a value equal to .500 . However, it was necessary to value each factor in an independent way considering its reliability level and the number of items. In this sense, for the Defensiveness II factor, a value over . 44 was accepted; for the Defensiveness I factor, a value over .28; and for the two factors left a minimum AVE of .25 (Moral, 2019). The convergent evidence was only supported by the Defensiveness factors (Table 4). About the discriminant evidence, it was evaluated through the HTMT ratio and was accomplished by the four factors, with values under .850 in all the cases (Table 4). Moreover, the latent correlations among the factors varied between -.095 and .725 (Table 4).

\section{Reliability}

Reliability was considered good for the four factors because of their being over 700 (Table 4). The ordinal alpha coefficient for each factor was between .734 (Defensiveness II) and .890 (Worry/Social anxiety). Likewise, the average inter-item correlation of the factors was found between .220 (Physiological anxiety) and .471 (Defensiveness II), indicating, on average, small and medium relationships between the items.

\section{Latent means differences according to gender and schooling level}

The comparison of means between males (reference group) and females indicated that there only existed small differences in the Defensiveness II factor, in favor of females (difference $=0.492$, effect size $=0.435$ ), in the other factors 
Table 4.

Convergent and discriminant evidence, correlations among factors, and reliability

\begin{tabular}{ccccccccccc}
\hline & & & & & & & \multicolumn{2}{c}{ Inter-item correlation } \\
\cline { 5 - 10 } Variable & PA & W/SA & D-I & D-II & $n$ & AVE & $\begin{array}{c}\text { Ordinal } \\
\text { alpha }\end{array}$ & $M$ & $S D$ \\
\hline PA & - & .738 & .334 & .425 & 12 & .235 & .773 & .220 & .105 \\
W/SA & .725 & - & .256 & .369 & 28 & .234 & .890 & .226 & .125 \\
D-I & -.253 & -.095 & - & .363 & 6 & .493 & .825 & .440 & .182 \\
D-II & .374 & .186 & -.341 & - & 3 & .500 & .734 & .471 & .104 \\
\hline
\end{tabular}

Note. Under the diagonal, the inter-factor correlations of the four-factor model modified of the CFA; over the diagonal, the HTMT ratio; PA = Physiological anxiety; W/SA = Worry/Social anxiety; D-I = Defensiveness I; D-II = Defensiveness II; $\mathrm{n}=$ Number of items; $\mathrm{AVE}=$ Average Variance Extracted; $\mathrm{M}=$ Mean; $\mathrm{SD}=$ Standard deviation .

the difference was trivial. On the other hand, regarding the comparison of means between the primary level (reference group) and the secondary level, small differences were observed in the Defensiveness I factor (difference $=$ -0.344 , effect size $=0.463$ ) and moderate differences in the Defensiveness II factor (difference $=0.421$, effect size $=0.699$ ), in the first case it was favorable to the primary students and in the second, to the secondary ones.

\section{Discussion}

Mental health is one of the main points in the agenda of different governments worldwide because its deterioration would have severe effects on people, and hence, on societies. Thus, disorders such as stress, depression, or anxiety are the ones that have received the most attention in the last year due to their constant increase. In this context, it is necessary to have measurement instruments that help these disorders diagnoses and, at the same time, permit to establish guidelines for their opportune treatment. In this way, the current study sought to cover that breach of knowledge, analyzing the RCMAS-2 psychometric properties in a sample composed of Peruvian children and adolescents.

The CFA was done testing different models found in the literature and the modified four-factor model was the one with the best goodness-of-fit indices. In this model, the items had factor loadings over .30, which can be seen as a very conservative criterion, however, previous studies have reported similar levels or even under them (Ang et al., 2011; Reynolds \& Richmond, 2008; Wu et al., 2016). The modified four-factor model, composed of Physiological anxiety, Worry/Social anxiety, Defensiveness I, and Defensiveness II, has been previously found in the studies by Zhu and Lowe (2017) and Cha et al. (2020). However, in studies that reported a structure of three or five factors, the correlation between the factors Worry and Social anxiety was high, with values such as .73 (Reynolds \& Richmond, 2008), .74 (Ang et al., 2011), and .77 (Lowe, 2014), justifying the combination of both factors into only one.

On the other hand, the modified four-model factor model has five correlated errors. These were added to the model because of their high modification indices and because their content justified their presence. The correlated errors between the items 23 with 37 and 4 with 10 have already been reported in the study by Zhu and Lowe (2017). Likewise, both pairs of items make up the Inconsistent responding index (Reynolds \& Richmond, 2008). Other groups of correlated errors correspond to item 17 with 10 and 17 with 4 , these three items share, in their phrasing, the fear of being laughed at by others. Finally, the correlation between the errors in items 23 and 41 was also highlighted by Zhu and Lowe (2017) since both items refer to the fear of talking in front of their partners during a class. It is important to add that all the referred items have been created for this new version of RCMAS-2 and are part of the Worry/Social anxiety factor.

Regarding RCMAS-2's equity, the modified four-factor structure remains invariant between males and females, as well as primary and secondary students. These results confirm what was found by Ang et al. (2011) and Lowe (2014) about the factorial invariance regarding gender.

Regarding the convergent and discriminant evidence, the study gives total support for the first and partial support to the second, because the factors Physiological anxiety, and Worry/Social anxiety were slightly under the established criterion. The results support what was found in previous research (Ang et al., 2011; Raad, 2013; Zhu \& Lowe, 2017).

The internal consistency reliability obtained satisfactory levels, similar to the studies by Lowe (2014) and Raad (2013) and superior to what was reported by Ang et al. (2011), Wu et al. (2016), Zhu and Lowe (2017), and Cha et al. (2020), 
where the Physiological anxiety factor had values under.70. Additionally, this coefficient was not remarkably high (.90 or superior), which indicates that the RCMAS-2 in the studied sample does not include redundant items (Streiner, 2003).

Finally, the comparison of latent means indicated that the defensiveness about positive aspects in females was slightly superior to the one in males (small effect), also found by Lowe (2014). However, the other factors' differences were null, different from what was found in other studies (Ang et al., 2011; Lowe, 2014; Wu et al., 2016). Regarding the schooling level, the differences were found in the factors of defensiveness, about positive aspects (superior in the primary) and negative aspects (superior in secondary).

One of the limitations of the study was the evaluation of reliability only through the internal consistency method because only one application is needed for its use. However, other studies have also evaluated RCMAS-2's temporary stability (Ahmad \& Mansoor, 2011; Ang et al., 2011; Cha et al., 2020; Raad, 2013). Another limitation was the use of methods for the collection of convergent and discriminant evidence that involve only RCMAS- 2 content when what is usual is to use other scales of measurement. The difficulty in this aspect was the lack of instruments that measure anxiety and are correctly adapted to the Peruvian population.

Future studies are necessary to examine the short version of RCMAS-2 (Lowe, 2015), given the current need to have brief instruments. Likewise, it is necessary to test the functioning of the full scale in a larger sample and with a larger representativeness of Peruvian population, in clinical as well as non-clinical samples.

Overall, the results of this study allow concluding that the RCMAS-2 scores have adequate psychometric properties in a group of Peruvian students and, hence, its use is pertinent, and it is a good alternative to measure anxiety in the educational context.

\section{References}

Ahmad, R., \& Mansoor, I. (2011). What I think and feel: Translation and adaptation of Revised Children's Manifest Anxiety Scale, Second Edition (RCMAS-2) and its reliability assessment. The International Journal of Educational and Psychological Assessment, 8(1), 1-11.

Aliaga, J. (2018). Psicometría: disciplina de la medición en psicología y educación. Fondo Editorial de la Universidad Inca Garcilaso de la Vega.

American Educational Research Association, American Psychological Association, \& National Council on Measurement in Education. (2014). Standards for educational and psychological testing. American Educational Research Association.

Ang, R. P., Lowe, P. A., \& Yusof, N. (2011). An examination of the RCMAS-2 scores across gender, ethnic background, and age in a large Asian school sample. Psychological Assessment, 23(4), 899-910. https://doi.org/10.1037/ a0023891

Ato, M., López, J. J., \& Benavente, A. (2013). A classification system for research designs in psychology. Anales de Psicología, 29(3), 1038-1059. https://doi.org/10.6018/ analesps.29.3.178511

Beaujean, A. A. (2012). BaylorEdPsych: R package for Baylor University educational psychology quantitative courses (Version 0.5) [Computer software]. https://cran.r-project. org/package $=$ BaylorEdPsych

Celis, J., Bustamante, M., Cabrera, D., Cabrera, M., Alarcón, W., \& Monge, E. (2001). Ansiedad y estrés académico en estudiantes de medicina humana del primer y sexto año. Anales de la Facultad de Medicina, 62(1), 25-30. https:// doi.org/10.15381/anales.v62i1.4143

Cha, Y. J., Lee, E.-H., Hwang, S.-T., Hong, S.-H., \& Kim, J.-H. (2020). Psychometric investigation of the Korean version of the Revised Children's Manifest Anxiety Scale, Second Edition. Korean Journal of Clinical Psychology, 39(3), 203-214. https://doi.org/10.15842/kjcp.2020.39.3.001

Cohen, J. (1988). Statistical power analysis for the behavioral sciences (2nd ed.). Lawrence Erlbaum Associates.

Cohen, Y., Kimball, H., \& Martinelli, K. (2018). Children's mental health report: Understanding anxiety in children and teens. Child Mind Institute.

DiStefano, C., Liu, J., Jiang, N., \& Shi, D. (2018). Examination of the Weighted Root Mean Square Residual: Evidence for trustworthiness? Structural Equation Modeling: A Multidisciplinary Journal, 25(3), 453-466. https://doi.org/ 10.1080/10705511.2017.1390394

Dominguez-Lara, S. (2019). Correlación entre residuales en análisis factorial confirmatorio: una breve guía para su uso e interpretación. Interacciones, 5(3), Article e207. https:// doi.org/10.24016/2019.v5n3.207

Domínguez, S., Villegas, G., \& Padilla, O. (2013). Propiedades psicométricas de la Escala de Ansiedad Manifiesta en NiñosCMASR en niños y adolescentes de Lima Metropolitana. Revista Peruana de Psicología y Trabajo Social, 2(1), 1532. http://revistas.uigv.edu.pe/index.php/psicologia/article/ view/48/57

Flora de la Barra, M. (2009). Epidemiología de trastornos psiquiátricos en niños y adolescentes: estudios de prevalencia. Revista Chilena de Neuro-Psiquiatría, 47(4), 303-314. https://doi.org/10.4067/S0717-92272009000400007

Gelaye, B., Tadesse, M. G., Lohsoonthorn, V., Lertmeharit, S., Pensuksan, W. C., Sanchez, S. E., Lemma, S., Berhane, Y., Vélez, J. C., Barbosa, C., Anderade, A., Williams, M. A. (2015). Psychometric properties and factor structure of the General Health Questionnaire as a screening tool for 
anxiety and depressive symptoms in a multi-national study of young adults. Journal of Affective Disorders, 187, 197202. https://doi.org/10.1016/j.jad.2015.08.045

Hair, J. F., Black, W. C., Babin, B. J., \& Anderson, R. E. (2019). Multivariate data analysis (8th ed.). Cengace Learning.

Hancock, G. R. (2001). Effect size, power, and sample size determination for structured means modeling and mimic approaches to between-groups hypothesis testing of means on a single latent construct. Psychometrika, 66(3), 373-388. https://doi.org/10.1007/BF02294440

Henseler, J., Ringle, C. M., \& Sarstedt, M. (2015). A new criterion for assessing discriminant validity in variance-based structural equation modeling. Journal of the Academy of Marketing Science, 43(1), 115-135. https://doi.org/10.1007/ s11747-014-0403-8

Instituto Nacional de Salud Mental. (2012). Estudio epidemiológico de salud mental de niños y adolescentes en Lima Metropolitana y Callao 2007. Anales de Salud Mental, 28(S1). https://bit.ly/3dTksQt

Instituto Nacional de Salud Mental. (2013). Estudio epidemiológico de salud mental en Lima Metropolitana y Callao Replicación 2012. Anales de Salud Mental, 29(S1). https:// bit.ly/3aFCnYO

Jorgensen, T. D., Pornprasertmanit, S., Schoemann, A. M., \& Rosseel, Y. (2021). SemTools: Useful tools for structural equation modeling (Version 0.5-4) [Computer software]. https://cran.r-project.org/package $=$ semTools

Keith, T. Z. (2019). Multiple regression and beyond: An introduction to multiple regression and structural equation modeling (3rd ed.). NY: Routledge.

Little, R. J. A. (1988). A test of missing completely at random for multivariate data with missing values. Journal of the American Statistical Association, 83(404), 1198-1202. https://doi.org/10.2307/2290157

Lowe, P. A. (2014). A closer look at the psychometric properties of the Revised Children's Manifest Anxiety Scale-Second Edition among U.S. elementary and secondary school students. Journal of Psychoeducational Assessment, 32(6), 495-508. https://doi.org/10.1177/0734282914528611

Lowe, P. A. (2015). The Revised Children's Manifest Anxiety Scale-Second Edition Short Form: Examination of the psychometric properties of a brief measure of general anxiety in a sample of children and adolescents. Journal of Psychoeducational Assessment, 33(8), 719-730. https://doi. org/10.1177/0734282915580763

Mahakwe, G., Johnson, E., Karlsson, K., \& Nilsson, S. (2021). A systematic review of self-report instruments for the measurement of anxiety in hospitalized children with cancer. International Journal of Environmental Research and Public Health, 18(4), Article 1911. https://doi.org/10.3390/ ijerph18041911

McCandless, B. R., Castaneda, A., \& Palermo, D. S. (1956). Anxiety in children and social status. Child Development, 27(4), 385-391. https://doi.org/10.2307/1125894
Ministerio de Salud. (2018). Plan nacional de fortalecimiento de servicios de salud mental comunitaria 2018 - 2021. Lima: Ministerio de Salud. http://bvs.minsa.gob.pe/local/ MINSA/4422.pdf

Moral, J. (2019). Revisión de los criterios para validez convergente estimada a través de la varianza media extraída. Psychologia, 13(2), 25-41. https://doi. org/10.21500/19002386.4119

Nunnally, J., \& Bernstein, I. (1994). Psychometric theory (3rd ed.). McGraw-Hill.

Orgilés, M., Méndez, X., Espada, J. P., Carballo, J. L., \& Piqueras, J. A. (2012). Síntomas de trastornos de ansiedad en niños y adolescentes: diferencias en función de la edad y el sexo en una muestra comunitaria. Revista de Psiquiatría y Salud Mental, 5(2), 115-120. https://doi.org/10.1016/j. rpsm.2012.01.005

Polanczyk, G. V, Salum, G. A., Sugaya, L. S., Caye, A., \& Rohde, L. A. (2015). Annual research review: A metaanalysis of the worldwide prevalence of mental disorders in children and adolescents. Journal of Child Psychology and Psychiatry, 56(3), 345-365. https://doi.org/10.1111/ jcpp. 12381

R Core Team. (2021). $R$ : A language and environment for statistical computing. R Foundation for Statistical Computing. https://www.r-project.org

Raad, J. M. (2013). Validation of the Revised Children's Manifest Anxiety Scale, Second Edition (RCMAS-2) scores for children with specific learning disabilities [Doctoral dissertation, University of Kansas]. KU ScholarWorks. http:// hdl.handle.net/1808/15092

Revelle, W. (2020). Psych: Procedures for psychological, psychometric, and personality research (Version 2.1.3) [Computer software]. https://cran.r-project.org/ package $=$ psych

Reynolds, C. R., \& Richmond, B. O. (1978). What I think and feel: A revised measure of children's manifest anxiety. Journal of Abnormal Child Psychology, 6(2), 271-280. https://doi.org/10.1007/BF00919131

Reynolds, C. R., \& Richmond, B. O. (2008). Revised Children's Manifest Anxiety Scale-Second Edition (RCMAS-2). Western Psychological Services.

Reynolds, C. R., \& Richmond, B. O. (2012). CMASR-2. Escala de Ansiedad Manifiesta en Niños Revisada: segunda edición. Manual Moderno.

Rosseel, Y. (2012). Lavaan: An R package for structural equation modeling. Journal of Statistical Software, 48(2), 1-36. https://doi.org/10.18637/jss.v048.i02

Rutkowski, L., \& Svetina, D. (2017). Measurement invariance in international surveys: Categorical indicators and fit measure performance. Applied Measurement in Education, 30(1), 39-51. https://doi.org/10.1080/08957347.2016.1243 540 
Shaffer, D., Fisher, P., Lucas, C. P., Ducan, M. K., \& SchwabStone, M. E. (2000). NIMH Diagnostic Interview Schedule for Children Version IV (NIMH DISC-IV): Description, differences from previous versions, and reliability of some common diagnoses. Journal of the American Academy of Child \& Adolescent Psychiatry, 39(1), 28-38. https://doi. org/10.1097/00004583-200001000-00014

Streiner, D. L. (2003). Starting at the beginning: An introduction to coefficient alpha and internal consistency. Journal of Personality Assessment, 80(1), 99-103. https://doi. org/10.1207/S15327752JPA8001_18

Vega, V., de Coll, J., Lermo, J., Escobar, J., Díaz, M., \& Castro, J. (2005). Niveles intelectuales y ansiedad en niños con intoxicación plúmbica crónica. Colegio "María Reiche". Callao-Perú, 2002. Anales de la Facultad de Medicina, 66(2), 142-147. https://revistasinvestigacion.unmsm.edu. pe/index.php/anales/article/view/1363/1158

Ventura-León, J., \& Peña-Calero, B. N. (2020). The world should not revolve around Cronbach's alpha $\geq .70$. Adicciones. https://doi.org/10.20882/adicciones.1576

World Health Organization. (2020, September 28). Adolescent mental health. https://www.who.int/news-room/fact-sheets/ detail/adolescent-mental-health
Wu, H., \& Estabrook, R. (2016). Identification of confirmatory factor analysis models of different levels of invariance for ordered categorical outcomes. Psychometrika, 81(4), 10141045. https://doi.org/10.1007/s11336-016-9506-0

Wu, L.-M., Liu, Y., Chen, H.-M., Tseng, H.-C., \& Lin, W.-T. (2016). Psychometric properties of the RCMAS-2 in pediatric cancer patients. European Journal of Oncology Nursing, 20, 36-41. https://doi.org/10.1016/j.ejon.2015.07.008

Zhu, Q., \& Lowe, P. A. (2017). Examination of the psychometric properties of the Revised Children's Manifest Anxiety ScaleSecond Edition scores among Chinese secondary school students. Journal of Psychoeducational Assessment, 36(7), 725-735. https://doi.org/10.1177/0734282917698302

Zickar, M. J. (2020). Measurement development and evaluation. Annual Review of Organizational Psychology and Organizational Behavior, 7(1), 213-232. https://doi. org/10.1146/annurev-orgpsych-012119-044957

Zumbo, B. D., Gadermann, A. M., \& Zeisser, C. (2007). Ordinal versions of coefficients alpha and theta for Likert rating scales. Journal of Modern Applied Statistical Method, 6(1), 21-29. https://doi.org/10.22237/jmasm/1177992180 